\title{
Stefan Biskupski
}

\section{Małżśenski Proces Skrócony}

Prawo Kanoniczne : kwartalnik prawno-historyczny 2/3-4, 43-66

1959

Artykuł został zdigitalizowany i opracowany do udostępnienia w internecie przez Muzeum Historii Polski w ramach prac podejmowanych na rzecz zapewnienia otwartego, powszechnego i trwałego dostępu do polskiego dorobku naukowego i kulturalnego. Artykuł jest umieszczony w kolekcji cyfrowej bazhum.muzhp.pl, gromadzącej zawartość polskich czasopism humanistycznych i społecznych.

Tekst jest udostępniony do wykorzystania w ramach dozwolonego użytku. 


\section{K8. STEFAN B I S K U P S K I}

\section{MAEZENSKI PROCES SKRÓCONY}

\section{$\S 1$. Pojęcie procesu skróconego i jego dzieje ${ }^{1}$}

Skrócony proces małżeński we współczesnym ustawodawstwie kościelnym istnieje na podobieństwo procesu uproszczonego w dawnym prawie; podobny też jest jego stosunek do procesu zwyczajnego. Jest to proces $w$ ścisłym tego słowa znaczeniu sądowy, gdzie ordynariusz występuje jako sędzia i gdzie ogłasza się wyrok, rozstrzygający spór na temat nieważności małżeństwa, $\mathrm{z}$ tym że procedura $\mathrm{w}$ procesie skróconym jest w wielu punktach odmienna od procedury procesu zwyczajnego.

Sformułowanie kan. $1990 \mathrm{w}$ tej części, która odnosi się do procedury spraw wyjętych ze zwyczajnego postępowania sądowego, mogło nasuwać wątpliwości, czy sprawy wymienione w tym kanonie należy rozpatrywać $w$ trybie sądowym, czy administracyjnym. Zagadnienie to nie istnieje dzisiaj, ponieważ rozstrzygnięte zostało przez Komisję. Interpretacyjną d. 6. XII. $1934 \mathrm{r}$.

Postawiono mianowicie następujące pytania:

I. Utrum casus excepti can. 1990 sint taxative, an demonstrative enuntiati.

1 Kan. 1990-1992; Doheny W., Canonical procedure in matrimonial cases, v. II, Informal procedure, Nilwaukee 1944; J o h n s o n J., De natura processuum matrimonialium exceptorum, Apollinaris 1936, 375 ns.; Wanenmacher F., Canonical evidence in mariage cases, Philadelphia 1935; Bisk upski S., Praw̄o matżeńskie, I, Warszawa 1856. 
II. Utrum processus, de quo in can. 1990, sit ordinis iudicialis, an administrativi

III. An momine ordinarii, de quo in can, 1990, veniat vicarius generalis, saltem de speciali mandato episcopi.

Resp. - Ad I et II. Affirmative ad primam partem; negative ad secundam.

Ad III. Negative2.

Dzieje procesu skróconego. Prawodawca kościelny dążył do skrócenia formalności sądowych w sprawach, kióre wymagały szybkiego ich załatwienia ze względu na dobro dusz ludzkich. Tak powstaly konstytucje Klemensa V (1305-1314) Dispendiosam i Saepe contingit, w których z jednej strony zezwala się na opuszczenie szeregu formalności procesowych wymaganych $\mathrm{w}$ zwyczajnym postępowaniu sądowym, z drugiej zaś wskazuje na sprawy, które moga być rozpatrywane w trybie skróconym, a jak nazywano dawniej - sumaryczym. Do tych spraw należały zawsze sprawy małżeńskie.

Dokumentem, który tworzy epokę w rozwoju procesu malżeńskiego, a właściwie stwarza cdrębny proces małżeński, wydzielony $z$ procesu cywilnego, jest konst. Benedykta XIV Dei miseratione. Na mocy „Dei miseratione” charak er ściśle sądowy procesu małżeńskiego zostaje w całej pełni utrzymany, ale musi w nim brać udzial obrońca węzła i dopiero po dwóch jednobrzmiących wyrokach za nieważnością malżeństwa wolno stronom wstępować w nowe związki.

Konstytucja Dei miseratione, tworząc odrębny zwyczajny proces małżeński, nie zamknęła drogi dla istnienia procesu skróconego. W wyjątkowych wypadkach już Benedykt XIV zezwalał na opuszczenie niektórych formalności, przewidzianych w Dei miseratione ${ }^{3}$. $\mathrm{Z}$ czasem prawo zwalniania od tych formalności udzielano niektórym biskupom ${ }^{4}$. Wreszcie dekretem Kon-

2 AAS 36 (1944) 94.

3 Decr. Etsi matrimonialis z 27. VIII. 1775 r., Bullarium Benedicti XIV, III, pars. II, p. 287.

4 Johns on J., art. c., Apollinaris, 1936, 379. 
gregacji św. Oficjum przewiduje się dla całego Kościoła wypadki, w których zachowanie przepisów Dei miseratione nie obowiązuje.

Dekret św. Oficjum z 5.VI. 1889 jest jednym ze źródeł do kan. 1990 i dlatego należy go tu jeszcze przypomnieć. Brzmi on następująco:

"Quando agitur de impedimento disparitatis cultus, et evidenter constat unam partem esse baptizatam, et alteram non fuisse baptizatam; quando agitur de impedimento ligaminis, et certo constat primum coniugem esse legitimum et adhuc vivere; quando denique agitur de consanguinitate aut affinitate ex copula licita, aut etiam de cognatione spirituali, vel de impedimento clandestinitatis in locis ubi decretum Trident. „Tametsi" publicatum est, vel tale diu observatur, dummodo ex certo et authentico documento, vel, in hujus defectu, ex certis argumentis evidenter constet de existentia hujusmodi impedimentorum super quibus Ecclesiae auctoritate dispensatum non fuerit; hisce in casibus, praetermissis solemnitatibus in const. apost. „Dei miseratione" requisitis, matrimonium poterit ab ordinariis declarari nullum, cum interventu tamen defensoris vinculi matrimonialis, quin opus sit secunda sententia"5.

Inny dekret tejże kongregacji św. Oficjum wydany został d. 10. VI.1896 r. z okazji wątpliwości, jaką przedstawił jeden z biskupów amerykańskich. Brzmi on następująco:

„Quatenus agatur de investigando impedimento dispartitatis cultus, quando contrahere volentes nullo praecedenti ligamine sunt innodati, si inquisitio respicit catholicos vel catholice educatos, etiam in defectu authentici documenti, ex quo constet fuisse revera baptizatos, uti baptizati habendi sunt in ordine ad matrimonium, nisi certo constet baptizatos non fuisse. Si agatur de haereticis vel ab haereticis baptizatis, dummodo constet de facto collationis baptismatis, et ipsius baptismatis invaliditas certo non constet, pariter uti baptizati habendi sunt in ordine ad matrimonium. Huiusmodi investigatio diligenter quidem sed etiarn extraiudicialiter et absque speciali delegatione fieri poterit. Si vero agatur de investigando impedimento disparitatis cultus ad effectum declarandi nullitatem vinculi praeexistentis, quo contrahere volentes sunt innodati, licet, ut $a b$ anno 1889 sub die 20 MIartii et iterum sub die 5 Iunii statuit haec ipsa S. Officii Congregatio, procedi possit praetermissis solemnitatibus in const. „Dei miseratione" requisitis, modo summario et extraiudiciali; semper tamen forma iudicialis quoad substantialia servari debet, cum interventu defensoris vinculi matrimonialis; et, si evidenter de impedimenti existentia constet ordinarius procedere potest ad proferendam nullitatis sententiam.

5 Fontes, IV, n. 1118. 
Planum est ex iis deducere quod in hoc secundo casu semper requiritur forma iudicii quoad substantiam nec non interventus defensoris vinculi matrimonialis; quod profecto praestari a nemine poterit, nisi. prius habita speciali ac regulari delegatione"6.

Powyższe dekrety, obok szeregu innych wypowiedzi Stolicy Ap., stworzyly podstawę dla prawa kodeksowego i sformułowania kan. 1990-1992 oraz art. 226-231 Instrukcji z r. 1936 w sprawie małżeńskiego skróconego procesu sądowego. W Instrukcji przy tym charakter sądowy skróconego procesu małżeńskiego jest podkreślony mocniej w stosunku do pewnych wyrażeń kodeksowych, które, jak wspomniano, mogły budzić wątpliwości.

W art. np. 227 Instrukcji Kongregacji Sakramentów z r. 1936 powiedziano o ordynariuszu, że występuje jako sędzia - „Ordinarius, iudicem agens"; w tym samym artykule użyto wyrażenia ściśle sądowego "matrimonii nullitatem sententia declarare"; $w$ art. 228 zezwala się oficjalowi - nie wikariuszowi generalnemu - na wydanie wyroku $\mathrm{w}$ procesie skróconym na podstawie specjalnych pelnomocnictw; zezwala się $\mathrm{w}$ art. 229 stronom i promotorowi sprawiedliwości na apelację do wyższej instancji; sędzia drugiej instancji nazwany jest $w$ art. 230 trybunałem drugiej instancji.

\section{§ 2. Cechy wyróżniające proces skrócony od zwyczajnego}

Można zapytać teraz, na czym polega proces skrócony i czym się różni od procesu zwyczajnego. Różnicę zasadniczą, gdy chodzi o stronę formalną, podkreślają słowa kan. 1990: "praetermissis sollemnitatibus hucusque recensitis" - z pominięciem formalności, o których była mowa $\mathrm{w}$ procesie $z w y-$ czajnym:

Wśród formaìności każdego procesu należy rozróżniać formalności istotne, bez zachowania których proces bylby nieważny $z$ samego prawa natury. Jasną jest rzeczą, iż takie formalności muszą być zachowane również $\mathrm{w}$ małżeńskim procesie skróconym. Są inne jeszcze formalności przewidziane

6 Fontes, IV, n. 1180. 
przez prawo kościelne, w celu uniknięcia różnych blędów i nadużyć przy wymiarze sprawiedliwości - formalności niejstotne; nie wszystkie $\mathrm{z}$ nich obowiązują $\mathrm{w}$ procesie skróconym.

W celach orientacyjnych zatem podajemy krótko, że w skróconym procesie małżeńskim przepisy co do właściwości sędziego i zdolności osób stawania w sądzie (zresztą z niewielkimi zmianami, o których będzie mowa niżej) obowiązują, jak w procesie zwyczajnym. Nie obowiązuje trybunał kolegialny, ani formalna skarga, lecz wystarcza zwykła prośba, wyrażona ustanie albo na piśmie. Udział obrońcy węzła jest konieczny. Z dowodów wymaga się tyik ko takie, które dowodzą autentyczności dokumentów i ich pewności. Nie ma ani publikacji akt, ani formalnego zamknięcia sprawy. Wyrok musi -odpowiadat wymogom wyroku w procesie zwyczajnym. Obowiązek apelacji ze strony obrońcy węzła jest tylko warunkowy, o ile uzna go w sumieniu swoim za konieczny?

Gdy chodzi następnie o postępowanie dowodowe, opiera sie ono głównie na dokumentach i dlatego skrócony proces małżeński nazywamy często procesem dokumentarnym.

\section{$\S 3$. Wypadki wyjęte od zachowania procesu zwyczajnego}

Kan. 1990 wymienia wypadki, w których zachowanie procesu zwyczajnego nie jest wymagane. Zachodzą one wtedy, gdy małżeństwo jest nieważne $z$ powodu istnienia następujących przeszkód zrywających, od których nie uzyskano dyspensy: różnej wiary, wyższych święceń, u roczystego ślubus węzła małżéskiego, pokrewieństwa. powinowactwa i pokrewienstwa duchowego.

$\mathrm{Na}$ wstępie powstaje zagadnienie, czy prawodawca wyliczyl wszystkie przeszkody, które służyć mogą za podstawę do wszczęcia procesu skróconego, czy też wymienił przeszkody przykładowo tylko, tak że inne tytuły nieważności małżeństwa mogłyby również stać się podstawą skróconego procesu. Chodziło zwłaszcza o przeszkodę braku wieku, która charakterem.

7 Por. Johns on J., art. c., 401. 
swoim odpowiada w zupełności wyliczonym w kan. 1990. Wśród kanonistów przeważała opinia, że prawodawca wyliczył przeszkody imiennie - taxative, co nie przeszkadzało im dorzucać do tego katalogu jednej, czy jeszcze drugiej. Dzisiaj sprawa jest wyjaśniona przez Komisję Interpretacyjną, że podstawę do procesu moga stanowić tylko i wyłącznie przeszkody wyliczone w kan. 1990.

We rn.z-Vidal uważał, że przy braku wieku, ponieważ o przeszkodzie tej można przekonać się ponad wszelką wątpliwość z ksiąg metrycznych, wolno również wszcząć proces skrócony8. Cocchi przypuszczal, że przeszkoda criminis ex adulterio cum publica attentatione matrimonii civilis może być punktem wyjścia do tego samego9.

Komisja Interpretacyjna d. 6. XII. 1943 na pytanie:

Utrum casus excepti can. 1990 sint taxative, an demonstrative enumerati, dała odpowiedź:

Affirmative ad primam partem; negative ad secundam10.

Ponieważ warunkiem koniecznym do tego, żeby sprawę można było prowadzić $w$ trybie postępowania skróconego, jest jedna $z$ przeszkćd wyliczonych w kanonie 1990, przeto naprzćd kilka słów ogólnie o tych przeszkodach, a potem krótko o każ$\operatorname{dej} z$ nich $z$ osobna.

1. Charakter przeszkód, wyliczonych w kan. 1990. Jednym z rodzajów przeszków małżeńskich są przeszkody publiczne i ta ne. W odróżnieniu od pojęcia publiczności i tajności, przyjętego w prawie karnym, przez przeszkodę publiczną rozumie się tę, której istnienia można dowieść na drodze sądowej. W wypadku przeciwnym mamy do czynienia z przeszkodą tajną. Nie chodzi tu zatem o znajomość przeszkody, lecz o możliwości jej udowodnienia w sądzie.

Kan. 27 prawa malżeńskiego dla Kościola Wschodniego, któremu odpowiada kan. 1037 Kodeksu Prawa Kan., tak określa przeszkodę publiczną: „Publicum censetur impedimentum quod publico ex facto oritur vel quod alio modo probari in foro externo potest; secus est

8 Wernz-Vida1, dz. c., V, 842, dop. 57.

9 Cocchi Gu., dz. c., 492 .

10 AAS 36 (1944), 96. 
occultum". Na sądzie można dowodzić przeszkody w różny sposób. A więc: 1-o dokumentami; 2-o zeznaniem co najmniej dwóch wiarogodnych świadków; 3-o zgodnymi opiniami dwóch ekspertów; 4-o przez fakt notoryczny itd. Jeżeli zatem przeszkodę jakąś będzie można udowodnić na sądzie jednym $\mathrm{z}$ wielu sposobów, przeszkoda jest publiczna.

Przeszkody, wyliczone imiennie w kan. 1990, a jest ich siedem, należą właśnie do przeszkód publicznych. W prawie przedkodeksowym o takich przeszkodach mówiono nawet, że są publiczne $z$ natury swojej, tzn. plyną $z$ faktu publicznego, jakim jest dokument, np. o zawartym małżeństwie, przyjęciu wyższych święceń, chrztu itd. Tego rodzaju przeszkód, choćby o nich nikt nie wiedział, gdy sprawa wejdzie na drogę sądową, nie da się ukryć; można je zawsze udowodnić przy pomocy najpewniejszego środka dowodowego, jakim jest dokument publiczny.

Tym się właśnie tłumaczy, że prawodawca kościelny w tych siedmiu wypadkach nieważności małżeństwa zezwala na odstępstwo od szeregu formalności, przewidzianych $\mathrm{w}$ procesie zwyczajnym i od niektórych postanowień zabezpieczających godność sakramentu małżeństwa, wprowadzonych jeszcze w konst. Dei miseratione. Tutaj, w wypadkach wyjętych, nie ma obawy o zniewagę sakramentu. Tutaj, w świetle dowodów opartych głównie na dokumentach publicznych, prawda o ważności lub nieważności małżeństwa staje się oczywista ponad wszelką wątpliwość.

Przejdźmy teraz do krótkiego omówienia każdej $z$ owych siedmiu przeszkćd.

2. Przeszkoda różnej wiary. "Różność wiary" disparitas cultus - $\mathrm{w}$ dzisiejszym ustawodawstwie kościelnym wywodzi się $\mathrm{z}$ różnicy, jaka zachodzi w wyznawaniu wiary, czy kultu w najogólniejszym znaczeniu pomiędzy osobą ochrzczoną $w$ Kościele Katolickim, albo nawróconą $z$ herezji czy schizmy i osobą nieochrzczoną w ogóle. Różność wiary stanowi przeszkodę zrywającą i dlatego, jeśli strona katolicka nie uzyskała dyspensy, jej małżeństwo $z$ osobą nieochrzczoną jest nieważne. Sprawa o ogłoszenie nieważności takiego malżeństwa może być rozpatrywana w trybie skróconym.

Prawo Kanoniczne - 4 
$\mathrm{Na}$ pojęcie przeszkody różnej wiary składają się zatem dwa elementy: 1-o chrzest $w$ Kościele Katolickim jednego z małżonków, albo przystąpienie do Kościoła z herezji lub schizmy; 2-o brak chrztu $u$ drugiego $z$ małżonków. Formułuje ją kan. $1070 \S 1 \mathrm{~W}$ słowach: „Nie ma małżeństwa pomiędzy osobą nieochrzczoną a ochrzczoną w Kościele Katolickim albo do niego nawróconą z herezji lub schizmy".

Nie ma wśród kanonistów zgody, gdy chodzi o ustalenie pojęcia „katolika" w zastosowaniu do kan. 1060 i 107011. Ogólna zasada głosi, iż za katolikà trzeba uważać tego, kto jest ochrzczony po katolicku i nie porzucił Kościoła, bez względu na to, czy obowiązki swej wiary wypełnia, czy też je zaniedbuje. Katolikiem jest także ten, kto zlożyż wyznanie wiary i zostal przyjęty w poczęt członków Kościola, choć był ochrzczony poza Kościołem. W szczególności należą do Kościoła:

1-o dzieci ochrzczone $w$ Kościele Katolickim za zgodą rodziców, czy opiekunów, - katolików lub akatolików, w celu zapisania ich do katolickiej społeczności kościelnej;

2-o dzieci rodziców akatolickich ochrzczone w niebezpieczeństwie utraty życia przez szafarza katolika; poza niebezpieczenstwem utraty życia ochrzczone za zgodą rodziców akatolików i jest pewność, że będą wychowane po katolicku; wreszcie pelne sieroty lub dzieci wyjęte spod opieki rodziców, jeżeli są ochrzczone po katolicku12.

3-o dorośli nieochrzczeni, którzy przez chrzest w Kościele Katolickim wyrażają życzenie należenia do Kościola;

4-o dorośli chrześcijanie innowiercy, którzy złożą wyznanie wiary i zostaną przyjęci do grona wiernych Kościoła Katolickiego, po ewentualnym ponowieniu chrztu, jeżeli co do jego ważności była wątpliwość.

3. Przeszkoda wyższych święceñ ${ }^{13}$. Kan. 1072 postanawia, że ,nieważnie usiłują zawrzeć małżeństwo duchowni wyższych święceń". Przeszkoda wyższych święcen stanowi zatem o prawnej niezdolności do zawarcia małżeństwa osoby, która przyjęla wyższe święcenia. Przez wyższe święcenia natomiast należy $w$ prawie rozumieć święcenia prezbiteratu, diakonatu i subdiakonatu ${ }^{14}$.

11 por. Biskupski S., Prawo matżeńskie, I, 145.

12 Kan. 750-751.

13 B iskupski S., Prawo matżńskie, I, 197 ns.

14 Kan. 949 
Do powstania tej przeszkody wymagana jest 1-o ważność święceń i 2-o brak przymusu $w$ przyjęciu święceń. Wymaga się tu ważności przynajmniej jednego $z$ wyższych święceń, ponieważ tylko ważne święcenia dają prawa i nakładają obowiązki. Jeżeli zatem z jakiegokolwiek powodu wszystkie święcenia - subdiakonatu, diakonatu i prezbiteratu - byly nie-ważne, nie było by przeszkody, toteż po uzyskaniu prawomocnego wyroku o nieważności święceń małżeństwo mogłoby być zawarte według przepisów prawa.

Do powstania tego rodzaju przeszkody wymaga się wolności w przyjęciu święceń. Przymus bowiєm, jakkolwiek zasadniczo nie wyłącza ważności święceń i praw z nich plynących, to jednak uwalnia od obowiązków. Wolność w przyjęciu święcen, począwszy od subdiakonatu, polega na świadomym pojmowaniu obowiązku zachowania celibatu i na braku przymusu do przyjęcia święceń. Dzisiaj, zwłaszcza po wyjściu instrukcji Kongregacji Sakramentów z 27. XII. 1930 r. ${ }^{15}$ o dopuszczaniu alumnów do święceń subdiakonatu, trudno przypuszczać, żeby ktoś nie znal obowiązku zachowania celibatu lub pod przymucem przyjmowal święcenia.

4. Przeszkoda uroczystego ślubu czystośc $\mathbf{i}^{16}$. Uroczystym ślubem nazywamy ślub publiczny, składany $w$ zakonie po uplywie trzech lat od złożenia ślubów zwyczajnych i uznany przez Kościół jako uroczysty. W istocie swej slub uroczysty nie różni się od zwykłego, a różnica między nimi zasadza się głównie na skutkach. Czynności mianowicie przeciwne ślubowi uroczystemu są nie tyiko niegodziwe, jak to ma miejsce przy ślubach zwyczajnych, ale także nieważne. Kan. 1073 tak postanawia: „Nieważnie również usiłują zawrzeć małżeństwo zakonnicy, którzy złożyli uroczyste śluby, albo śluby proste, do których, na mocy specjalnego przepisu Stolicy Ap., dodana jest siła unieważniająca małżeństwo".

Wynika z tego, że przeszkodą uroczystego ślubu czystości objęci są zakonnicy i zakonnice, którzy złożyli uroczyste śluby.

18 AAS 23 (1931) 120.

16 Biskupski S., j. w., 206. 
oraz ci, którzy złożyli śluby proste, ale przywiązana jest do nich, na mocy specjalnego zarządzenia Stolicy Ap., klauzula unieważniająca małżeństwo, jak np. śluby proste scholastyków jezuickich, po dwuletnim nowicjacie ${ }^{17}$.

Warunkiem powstania przeszkody jest ślub złożony ważnie i nadal istniejący.

Do ważności ślubu, wedlug kan. 572, wymagane są następujące warunki: wiek; dopuszczenie przez przełożonych; ważnie odbyty nowicjat; dobrowolna profesja; profesja dokonana wyraźnie; przyjęcie jej stosownie do konstytucji przez wlaściwego przełożonego lub jego delegata; uprzednie złożenie profesji zwykłej. Brak któregokolwiek z tych warunków powoduje nieważność ślubów.

5. Przeszkoda węzła małżeńskiego ${ }^{18}$. Istniejące ważnie małżeństwo, choćby tylko zawarte i nie dopelnione, stanowi przeszkodę węzła. Przeszkoda węzła wypływa z zasady postawionej wyraźnie przez Chrystusa P., że małżeństwo wśród ochrzczonych jest nierozerwalne. Dlatego też, dopóki małżeństwo nie przestanie istnieć przez śmierć jednego ze wspó1małżonków lub nie zostanie uznane na drodze prawnej jako nieważne, tj. niebyłe i nieistniejące, dotąd żadne ze wspólmałżonków nie może ważnie zawrzeć innego małżeństwa. W ten sposób przeszkoda węzła uniemożliwia równoczesną poligamię (poligynię lub poliandrię).

Przeszkoda węzła istnieje, gdy małżeństwo jest ważne i nie rozwiązane. Jak wiadomo, małżeństwo może być nieważne z trzech zasadniczych tytułów: 1-o gdy osoby są niezdolne pod względem prawnym do zawarcia małżeństwa, czyli inaczej, gdy zachodzi przeszkoda zrywająca; 2-o gdy brak zgody na zawarcie małżeństwa u którejkolwiek ze stron i 3-o gdy brak należytej formy zawarcia. Jeżeli żadnego $\mathrm{z}$ tych trzech tytulów dopatrzeć się nie można, albo jeżeli nawet byl, ale małżeństwo zostało uważnione $\mathrm{w}$ sposób zwykły, czy też przez uzdrowienie $\mathrm{W}$ zawiązku, to powstal węzel, który stał się

17 Konst. Grzegorza XIII Ascedente Domino z 25. V. 1584 r.; Fontes, I, n. 153 .

18 B iskupski S., j. w., 185. 
podstawą przeszkody zrywającej w stosunku do nowego mążeństwa, jakie usiłowałaby zawrzeć którakolwiek ze stron.

Małżeństwo ważne rozwiązuje się zasadniczo przez śmierć współmałżonka, a poza tym $w$ wypadku tzw. przywileju Pawłowego ${ }^{19}$, małżeństwo nie dopełnione natomiast przez dyspensę papieską i przez uroczystą profesję zakonną ${ }^{20}$.

6. Przeszkoda pokrewieństwa ${ }^{21}$. Nie kaźde pokrewieństwo stanowi przeszkodę zrywająca małżeństwo. Prawo wprowadza tu ograniczenie $w$ linii bocznej co do stopni i uwielokrotnienia. Zakres zatem przeszkody jest różny w zależności od linii i stopnia pokrewieństwa.

W linii prostej małżeństwo jest nieważne ze wszystkimi wstępnymi i zstępnymi na zawsze. Kodeks Prawa Kan. tak to ujmuje: „W linii prostej pokrewieństwa małżństwo jest nieważne między wszystkimi wstępnymi i zstępnymi tak prawnymi, jak naturalnymi". W linii natomiast bocznej przeszkoda jest ograniczona do trzeciego stopnia włącznie. Gdyby przeto pokrewieństwo było $\mathrm{w}$ stopniu nierównym i wykraczało jednym ramieniem poza trzeci stopień, przeszkody nie ma. Nie ma więc przeszkody między krewnymi w stopniu czwartym, łączącym się ze stopniem trzecim, drugim lub pierwszym.

Inne ograniczenia przeszkody pokrewieństwa dotyczą uwielokrotnienia pokrewieństwa. Przeszkoda mianowicie uwielokrotnia się tylko wtedy, gdy pokrewieństwo staje się wielo. krotne $\mathrm{z}$ racji powtarzania się wspólnego pnia w obrębie trzech uniemożliwiających małżeństwo stopni.

7. Przeszkoda powinowactwa ${ }^{22}$. Z małżeństwa ważnie zawartego, pomiędzy jednym z małżonków a krewnymi drugiego, powstaje bliskość osób, którą nazywamy powinowactwem. Zródłem powinowactwa nie jest zatem współżycie cielesne, jak to było $\mathrm{w}$ prawie przedkodeksowym, lecz ważne przedmiotowo małżeństwo, węzeł małżeński, zadzierżgnięty

\footnotetext{
19 Kan. 1120.

20 Kan. 1119.

21 B iskupski S., j. W., 225.

22 Biskupski S., j. w., 242.
} 
w chwili ślubu, bez względu na to, czy nastąpiło potem pożycie, czy nie.

Powinowactwo zachodzi wyłącznie pomiędzy mężem a krewnymi żony i odwrotnie - pomiędzy żoną a krewnymi męża. Tak pojęte powinowactwo $\mathrm{w}$ linii prostej stanowi przeszkode zrywającą w jakimkolwiek stopniu, w linii zaś bocznej - tylko do drugiego stopnia włącznie. Dlatego też gdyby $w$ ramieniu dluższym powinowactwo sięgało stopnia trzeciego, przeszkody nie ma. Podobnie jak pokrewieństwo, również i powinowactwo może być wielokrotne. Ma to miejsce, gdy uwielokrotnia się pokrewienstwo, cd którego powinowactwo pochodzi i gdy ponawia się kolejno małżeństwo $\mathrm{z}$ krewnym zmarłego małżonka. Wraz z powinowactwem uwielokrotnia się wtedy i przeszkoda zrywająca.

8. Przeszkoda pokrewieństwa duchoweg o ${ }^{23}$. Przez analogię do pokrewieństwa fizycznego i do powinowactwa wprowadził Kościół pokrewieństwo duchowe, którego podstawą istnienia były dawniej sakramenty chrztu i bierzmowania, a dzisiaj tylko sakrament chrztu. Pokrewieństwo duchowe zatem jako przeszkoda zrywająca do zawarcia maìżeństwa jest to bliskość osób, powsiała ze chrztu św., ze zrodzenia się niejako do życia chrześcijańskiego, do życia nadprzyrodzonego w Kościele. Pojęcie pokrewieństwa duchowego ujmuje Kodeks Prawa Kan. w następujących słowach: „Pokrewieństwo duchowe zaciągają ze chrztu $z$ ochrzczonym tylko chrzczący i chrzestny"24. Tak tez pojęte pokrewieństwo duchowe stanowi przeszkodę ${ }^{25}$.

Do istnienia tej przeszkody wymaga się pewnych warunków. Ze strony zatem tego, kto udziela chrztu, wymaga się, żeby sam był ochrzczony, ponieważ osoby nieochrzczone nie podlegaja prawom Kościoła i nie może być pokrewieństwa duchowego tam, gdzie obie strony nie podlegają prawom Kościoła. Gdy chodzi o rodziców chrzestnych, wymaga się, żeby do chrztu podawali ważnie, stosownie do przepisów kan. 765 .

23 B iskupski S., j. w. 256.

24 Kan. 768.

25 Kan. 1079. 
Ze strony wreszcie tego, kto przyjmuje chrzest, wymaga się, żeby był faktycznie ochrzczony ważnie, tj. zyskał łaskę sakramentalną przez znak zewnętrzny. Stąd jest rzeczą obojętną, czy chrzest jest uroczysty, czy prywatny - w jednym i drugim wypadku zaciąga się pokrewieństwo; same natomiast uzupełniające ceremonie chrzestne nie powoduja pokrewieństwa duchowego, a co za tym idzie nie stwarzają żadnej przeszkody.

$\S 4$. Brak dyspensy od jednej z wyliczonych przeszkód ${ }^{26}$

Wyliczone w kan. 1990 wypadki, a omówione tu krótko, mogą stać się podstawą do skróconego procesu małżeńskiego pod warunkiem, że od tych przeszkód nie udzielono dyspensy, czyli że te przeszkody nie przestały istnieć: „gdyby... zarazem $\mathrm{z}$ równą pewnością okazało się, że dyspensa od tych przeszkód nie została udzielona" - głoszą słowa kan. 1990.

Dla ścisłości jednak trzeba tu wyjaśnić, że nie od wszystkich wymienionych przeszkód może być udzielona dyspensa. Jedna bowiem $\mathrm{z}$ nich - węzeł małzeński, została ustanowiona przez Chrystusa P., inna - pokrewieńsiwo, przynajmniej $\mathrm{w}$ pierwszym stopniu linii prostej, pochodzi $z$ prawa naturalnego; jeszcze inna - święcenia prezbiteratu - pochodzi wprawdzie $z$ prawa kcścielnego, ale prawcdawca nie zwykł od niej dyspensować. Gdy mowa zatem o braku dyspensy, trzeba mieć na uwadze przeszkody, od których można uzyskać dyspensę.

Ponieważ, jak wiemy, omawiane przeszkody są publiczne, przeto i dyspensy, o ile zachcdzą warunki do jej uzyskania, udziela się publicznie, to znaczy na piśmie. Dla'ego łatwo jest dowieść, że udzielono dyspensy lub jej odmówiono.

§ 5. Stwierdzenie faktu istniejącej przeszkody i braku od niej dyspen:y

Istnienia jednej z wyżej wyliczonych przeszkód i braku od niej dyspensy dowodzi się zasadniczo przy pomocy dokumentów.

20 Biskupski S., j. w., 113 ns. 
Dokumentem sądowym nazywamy pismo, które na rozprawie ma dowieść jakiegoś faktu; w procesię skróconym ma dowieść konkretnie istnienia jednej $\mathrm{z}$ siedmiu przeszkód, wyliczonych w kan. 1990.

Spośród różnych dokumentów ma dla nas największe znaczenie dokument oryginalny, uwierzytelniony jego odpis, dokument autentyczny, ważny, pewny. Kan. 1990 podaje zaraz na wstępie: ,Gdyby wiadome bylo z pewnego i autentycznego dokumentu, który nie podlega żadnemu zaprzeczeniu i sprzeciwowi..." Wynika $z$ tego, że prawodawcy zależy glównie na tym, żeby dokument był pewny i autentyezny. Dokument zaś jest pewny, gdy nie można wątpić o jego a) istnieniu, b) o jego prawdziwości i c) o jego treści.

Może się bowiem zdarzyć, że chrztu np. udzielał proboszcz $i$ on téz podpisal metrykę, ale tajnie przystąpił do sekty, w której udziela się chrztu nieważnie. W danym wypadku świadectwo chrztu nie jest pewne, ponieważ można wątpić, czy proboszcz, który prawdopodobnie już należał do sekty, ochrzcił ważnie. Jego zatem podpis jako proboszcza, choć autentyczny, nie daje pewności o prawdziwej treści dokumentu, czyli o rzeczywistości stwierdzanego faktu.

Prawodawca wymaga następnie, żeby dokument był autentyczny. Dokumentem auteniycznym nazywamy albo sam oryginał, co do którego nie ma najmniejszej wątpliwości, że został sporządzony przez tego, kto go podpisał lub przynajmniej sporządzony był $\mathrm{z}$ polecenia tego, kto podpisywał świadomie, $\mathrm{w}$ pełni władz umysłowych, albo - uwierzytelniony odpis $\mathrm{z}$ oryginału, po dokładnym sprawdzeniu, czy jest $\mathrm{z}$ nim zgodny i podpisany przez urzędnika publicznego, oraz opatrzony urzędową pieczęcią. Dokument wreszcie, który w małżeńskim procesie skróconym ma świadczyć o istnieniu przeszkody musi być poza wszelką wątpliwością - quod nulli contradictioni vel exceptioni obnoxium, wziąwszy pod uwage podpisy, pieczęcie i inne oznaki autentyczności, które uzna ordynariusz, po wysłuchaniu i rozpatrzeniu wniosków obrońcy węzła ${ }^{27}$.

27 Por. Johnson J., Ius vigens de processibus matrimonialibus exceptis, Apollinaris 1936, 629. 
Publicznymi dokumentami autentycznymi są reskrypty Stolicy Ap. kongregacji rzymskich, ordynariuszów, gdy pełnią urząd a sporządzonę są w przyjętej formie; świadectwa wystawione przez notariuszów kościelnych; sądowe akta kościelne; $w$ szczególności mają tu wielkie znaczenie metryki chrztu, święceń, profesji zakonnej, zawartych malżeństw, zmarłych itp28.

W zasadzie publiczne dokumenty panstwowe mają również wartość pełnego dowodu. W praktyce jednak trzeba być ostrożnym, zwłaszcza gdyby chodziło o wolny stan jakiejś osoby, względnie o świadectwo zgonu, ponieważ, jak to miało miejsce w okresie wojny, wladze państwowe wydawały po upływie określonego ustawowo okresu czasu świadectwa zgonu o osobach zaginionych, których śmierci nie stwierdzono. Świadectwo takie wydawano dla celów majątkowych i rozwodowych.

Podobnie przedstawia się sprawa $z$ dokumentami prywatnymi. I one w zasadzie wystarczają. W rzeczywistości jednatz. rzadko zdobywa się pewność, że są prawdziwe i autentyczne.

Skrócony proces małżenski moinna zastosować nie tylko wówczas, gdy dokumenty i inne dowody przy stwierdzeniu faktu, że istnieje przeszkoda, są ponad wszelką wątpliwośc pewne, ale nadto ponad wszelką wątpliwość zostało udowodnione, że przeszkoda istnieje nadal, ponieważ nie było od niej dyspensy. Ta sama musi istnieć pewność w stosunku do obydwu faktów - istnienia przeszkody i braku dyspensy.

In ne dow ody. Proces skrócony nazywa się często procesem dokumentarnym, ponieważ głównymi dowodami, które mają świadczyć o nieważności mał̇eństwa, są dokumenty. Dokumenty jednak są wprawdzie głównymi dowodami, ale nie jedynymi. Często bowiem, zwłaszcza gdy chodzi o stwierdzenie, że nie udzielono dyspensy, nie może być dokumentu i dlatego $w$ procesie tym wolno dopuścić inny także dowód; byleby dowód ten co do pewności faktu samego nie pozostawiał najmniejszej wątpliwości. Dowodem takim doskonale może być świadek kwalifikowany, jak np. proboszcz w wy-

28 Kan. 1813. 
padku zaginięcia ksiąg metrykalnych lub wikariusz generalny i notariusz kurialny w wypadku braku dyspensy ${ }^{29}$.

Ponieważ dopuszczenie innych dowodów, niż opartych na dokumentach, budziło wątpliwości, przeto zwrócono się do Komisji Interpretacyjnej o wyjaśnienie.

Pytanie brzmialo następująco:

Utrum "par certitudo", de qua in canone 1990, haberi possit tantum ex certo et authentico documento; an etiam ex alio legitimo modo.

Odpowiedź była: Negative ad primam partem; affirmative ad secundam.

Udzielono jej d. 16. VI. 1931 r.30

§ 6. Trybunał $\mathrm{w}$ małżeńskim procesie skróconym

1. Ordynariusz jako sędzia, a w jego zastępstwie oficjal. Art. 227 Instrukcji z r. 1936, uzupełniając słowa kan. 1990, po wyrazie "ordinarius" dodaje "iudicem agens". Potwierdza się $\mathrm{w}$ tych słowach zasad.̨, że proces skrócony jest procesem ściśle sądowym. $\mathrm{Z}$ zasady tej płynie również wniosek, że $\mathrm{w}$ procesie $\nmid \mathrm{ym}$ nie może występować wikariusz generalny, ponieważ art. $3 \S 2$ tejże Instrukcji wyraźnie postanawia, że „pod mianem ordynariusza $w$ tej instrukcji nie należy pojmować, gdy chodzi o czynności sądowe, ani wikariusza generalnego, ani przełożonych zakonnych". W procesie skróconym zatem sędzią zwyczajnym, ze względu na wyjątkowy charakter tego procesu, jest bezpośrednio sam ordynariusz miejscowy i on osobiście bierze odpowiedzialność za przebieg i wynik sprawy. Dopiero w razie nieobecności ordynariusza lub gdyby obowiązków swoich nie mógł pełnić, zastępuje go oficjał do tego specjalnie upoważniony ${ }^{31}$. Wynika $\mathrm{z}$ tego, że trybunał $\mathrm{w}$ procesie skróconym jest jednoosobowy.

29 Por. Johnson J., j. w., 631.

30 AAS 23 (1931) 353.

31 Art. 228. 
W praktyce, zwlaszcza w rozległych diecezjach, jak np. w Polsce, ordynariusz, mianując oficjała, powierza mu nie tylko wszystkie sprawy rozpatrywane $w$ zwykłym postępowaniu sądowym, ale $i$ sprawy rozpatrywane $w$ trybie skrócnym; ordynariusz deleguje $w$ ten sposób oficjała na stałe do badania i osadzania spraw z kanonu 1990. Ze względu jednak na brzmienie artykułów 227 i 228 Instrukcji, wypada, żeby ordynariusz po zakończeniu skróconego przewodu sądowego, po zreferowaniu sprawy przez oficjała i zapoznaniu się z aktami sprawy, sam decydowal i podpisywal wy rok.

Jeżeli w tych sprawach oficjał otrzymał delegację, jak wyżej, delegacja ta jest dana industria personae, toteż nie mógłby on subdelegować $\mathrm{w}$ poszczególnej sprawie innej osoby do sądzenia sprawy. Mógłby to uczynić tylko sam ordynariusz, jakkolwiek nie powinien tego czynić, ze względu na ważność tych spraw i na powagę sądową oficjała32.

2. Obrońca węzła. W mał̇żńskim procesie skróconym występuje obrońca węła $z$ urzędu. Podobnie jak $w$ procesie zwykłym, jego udzial jest konieczny do ważności samego procesu ${ }^{33}$. Działalność swoją w obronie sakramentu małżeństwa obrońca węzła rozwija wszystkimi przewidzianymi przez prawo sposobami. Ma wgląd w akta, bierze czynny udział przy badaniu prawdziwości i autentyczności dokumentów i braku dyspensy, układa pytania dla stron i ewentualnie dla świadków, jest obecny przy ich zeznaniach, składa swój umotywowany whiosek przed wyrokiem, wreszcie może apelować od wyroku uznającego nieważność małżeństwa, jeżeli w sumieniu swoim uzna, że apelacja jest potrzebna.

3. Promotor sprawiedliwości. O promotorze sprawiedliwości $\mathrm{w}$ procesie skróconym wyraźnie wspomina Instrukcja w art. 227, gdzie powiedziano, że ordynariusz musi wysłuchać opinii promotora sprawiedliwości, jeżeli on zaskarżył małżeństwo, albo gdy $\mathrm{w}$ ogóle uzna to za właściwe.

Omawiany artykuł Instrukcji o udziale promotora sprawiedliwości należy brać łącznie $z$ art. 16, gdzie udział promotora sprawiedliwości określono jako obswiązkowy nie tylko wtedy, gdy skarży on malżeńsiwo, ale również i wtedy, gdy chodzi

32 Por. Doheny W., Informal procedure, 123 ns; Johns on J., j. W. 616 .

33 Kan. 1990, 1992; art. 227-230. 
o przestrzeganie przepisów procesowych - „ubi de lege processuali tutanda agitur". Ponadto, jak wiemy, promotor spra-wiedliwości występuje zawsze tam, gdzie dobro publiczne Kościoła tego wymaga. W świetle tych uwag stają się dopiero w pełni zrozumiałe słowa omawianego artykułu o udziale promotora sprawiedliwości $w$ małżeńskim procesie skróconym.

4. Notariusz. Zrozumiała jest rzeczą, że tam, gdzie sporządza się urzędowy protokół, musi być przy tym notariusz, ponieważ do jego obowiązków należy sporządzanie i troska o urzędowe akta, a w procesie sądowym - o akta sądowe. Akta powinny być podpisane przynajmniej przez notariusza; inaczej są nieważne ${ }^{34}$. Stąd ordynariusz, czy oficjal, zanim przystąpi do rozpatrzenia sprawy, musi wyznaczyć jednego z notariuszów Kurii lub zamianować notariusza specjalnie dla sprawy, która ma być osądzona $w$ trybie skróconym. Jego prawa i obowiązki są takie same, jak notariusza w procesie zwykłym.

\section{$\S 7$. Strony $\mathrm{w}$ procesie skróconym}

Ogólne zasady prawne odnoszące się do stron w procesie mają zastosowanie także do procesu skróconego. Strony zatem łącznie $z$ promotorem sprawiedliwości mają przede wiszystkim prawo skargi. Udział promotora sprawiedliwości przy zaskarżaniu małżeństwa $w$ procesie skróconym jest nawet szerszy, niż w procesie zwykłym. W procesie bowiem dokumentarnym podstawą nieważności małżeństwa są wyłącznie przeszkody publiczne nie tylko $z$ natury, ale $i$ faktycznie. Obok jednak promotora, prawo to $w$ zasadzie przysługuje małżonkom, o ile nie są sprawcami nieważności i mają prawo stawania w sądzie ${ }^{35}$.

Zaznaczyć tu należy, że $w$ procesie zwykłym akatolicy ochrzczeni lub nieochrzczeni nie mają prawa zaskarżania swojego malżeństwa

34 Kan. 1585.

35 Kan. 1971. 
przed sądami kościelnymi. Ponieważ na tym tle były wątpliwości, Kongregacja św. Oficjum na pytanie: „Utrum in causis matrimonialibus acatholicus, sive baptizatus, sive non baptizatus, actoris partes agere possit, dnia 27. I. 1928 r. dała następujące wyjaśnienie:

Negative, seu standum C. J. C., praesertim can. 87. Si quidem autem speciales occurrant rationes ad admittendos acatholicos ut actores in hujusmodi causis, reccurrendum ad S. C. S.. Officii in singulis casibus 36 .

W tej sprawie wielu kanonistów stoi na stanowisku, że wyjaśnienie Kongregacji św. Oficjum odnosi się tylko do procesu zwykłego, że $\mathrm{w}$ procesie skróconym akatolik ma prawo wystąpić $w$ charakterze powoda. Kanoniści powołują się na. praktykę św. Oficjum, np. w sprawie, jaką wniósł biskup z Harrisburg, na którą otrzymał d. 20.IV.1931 odpowiedź kongregacji następującej treści: „Haec suprema S. Congregatio, re diligenter considerata, respondendum mandavit, praefatum casum ab ipso ordinario pertractari posse ad normam canonum 1990-1992". Ponieważ poglądu takiego bronią kanoniści tej miary, co G a s parri37, a dalej Doh en y38, Johnson39, Park40, i in., przeto tuta conscientia można przyjmować prośby akatolików, jeżeli chodzi o proces dokumentarny.

\section{$\S$ 8. Przewód sądowy w procesie skróconym}

Jedną z cech zasadniczych małżeńskiego procesu skróconego jest zachowanie formalności koniecznych do wykrycia prawdy, a opuszczenie tych, które procesowi zwykłemu nadają charakter uroczysty. Zasada ta ,praetermissis sollemnitatibus" odnosi się do wszystkich czynności sądowych.

Skarga, która spór oddaje sądowi do rozstrzygnięcia, może być bardziej lub mniej uroczysta. W procesie skróconym nie musi ona odpowiadać wszystkim przepisom kan. 1706-1710. Wystarczy, że w prośbie wskaże się: a) sąd właściwy, b) prośbę o ogłoszenie nieważiości małżeństwa, c) przeszkodę zry.

36 AAS 20 (1928) 75.

37 Tractatus can. de matrimonio, II, 293.

$38 \mathrm{Dz} ., \quad c ., 152$.

$39^{\circ}$ J. W., 620 .

40 Park C., Competence of Ordinary in a case under conon 1990. The Ecclesiastical Review, Philadelphia 1932, 68 ns. Por. także Ius Pontificium, 12 (1932), 134. 
wająca i brak dyspensy, d) dowody, jakie strona załącza lub. zamierza przedstawić, e) podpis, dokładne adresy i datę.

Niezależnie od stron, sprawę wnieść może promotor sprawiedliwości na skutek czyjegoś doniesienia albo z polecenia ordynariusza, jak $\mathrm{w}$ procesie zwykłym. Jego skarga musi. równiez posiadać to, co jest istotne.

Skarge może strona złożyć za pośrednictwem swego duszpasterza, który przedistawia ją ustnie albo na piśmie, bezpośrednio lub przez pocztę. Notariusz zapisuje ją w aktach z zaznaczeniem wszystkich bardziej znamiennych okoliczności.

1. Wstępne badanie skargi. Oficjał bada skarge i przedstawione dokumenty, czy odpowiadaja warunkom. przewidzianym w kan. 1990 i czy sprawa nadaje się do postępowania skróconego. Jeżeli uzna za stosowne, zasięga opinii obrońcy węzła. Szczególną uwagę przy tym wstępnym badaniu należy zwrócić na prawdziwość i autentyczność dokumentów. W tym celu, gdyby chodziło o dokumenty spoza diecezji, można i trzeba zwrócić się do ordynariusza diecezji, w której zostały wystawione, o sprawdzenie ich prawdziwości. To samo trzeba powiedzieć i o innych dowodach, gdyby zachodzilo jakiekolwiek podejrzenie ${ }^{41}$.

Wyniki wstępne badania oficjał referuje ordynariuszowi, który decyduje, czy sprawa ma być rozpatrywana w trybie skróconym. Jeżeli tak, wyznacza się dzień i godzinę, na którą wzywa się strony i obrońce węża, kióry uprzednio rna przygotować odpowiednie pytania.

Zanim ordynariusz jednak zadecyduje o małżeńskim procesie skróconym, musi zdobyć moralną pewność, że przeszkoda istnieje, że nie została od niej udzielona dyspensa i że małżeństwo nie zostało uważnione.

Fakt przyjęcia sprawy do rozstrzygnięcia w trybie uproszczonym musi być podany w aktach.

2. Wezwanie stron. Strony wzywa sie w sposób zwykły przez specjalne pozwy, które muszą odpowiadać przepisom prawa, podanym $w$ procesie zwyczajnym.

41 Art. 226. 
3. Postępowanie dowodowe i wyrok. W dniu oznaczonym ordynariusz lub oficjał do tego upoważniony przesłuchuje strony - naprzód powoda potem stronę pozwaną, które składają przysięgę przed i po złożeniu zeznań. Przesłuchanie odbywa się $\mathrm{w}$ obecności obrońcy węzła i, jeżeli bierze udział $\mathrm{w}$ sprawie, promotora sprawiedliwości, według pytań, które ułożył obrońca węzła i ewentualnie promotor sprawiedliwości. Notariusz zapisuje odpowiedzi zasadniczo por dyktando sędziego.

$W$ procesie tym nie ma zawiązania sporu.

Gdyby która ze stron, pomimo doręczonego jej wezwania. nie chciała stawié się na rozprawę, może być ogłoszona jako oporna prawu i sprawa toczy się dalej.

Zarówno stronom, jak obrońcy węzła i promotorowi sprawiedliwości, przysługuje prawo skỉadania ekscepcji i zglaszania świadków. Gdyby jdnak ekscepcje wymagały doda.kowego bađania, sędzia rozważy, czy sprawy nie należałoby odesłać do rozpatrzenia $w$ trybie zwykłego postępowania.

Postępowanie dowodowe zmierza, jak już powiedziano, do tego głównie, żeby wykryć czy istnieje przeszkoda i czy nie udzielono dyspensy lub nie uważniono małżeństwa.

$W$ procesie tym nie ma ani formalnej publikacji akt, ani zamknięcia sprawy. Obrońca węzła wydaje swoją opinię umotywowaną in iure et in facto na piśmie.

Gdy sprawa jest dostatecznie wyjaśniona i sędzia nabierze morainej pewności, że małżeństwo jest nieważne, ogłasza wiyrok. Wyrok musi odpowiadać wszystkim warunkom, jakie prawo przewiduje dla wyroku w procesie zwyczajnym.

\section{$\S 9 . \quad$ Apelacja}

Obrońca węzła, jeżeli w sumieniu swoim uważa, że przeszkoda nie jest pewna, lub że możliwe było udzielenie od niej dyspensy, ma prawo złożyć apelację do wyższej instancji ${ }^{42}$.

Wbrew jednak podstawowej zasadzie o obowiązkach obroncy węzła $w$ procesie zwyczajnym, nie ma on obowiązku bez-

42 Art. 229. 
względnego odwoływania się od każdego wyroku. To jest właśnie jedna $\mathrm{z}$ kilku charakterystycznych cech procesu skróconego. Decyduje tu o obowiązku obrońcy węzła jego własne sumienie.

Prawo składania apelacji przysługuje również stronom i promotorowi sprawiedliwości.

Jeżeli obrońca węzła lub którakolwiek ze stron pragnie skorzystać z prawa odwołania się do wyższej instancji, obowiązuje wtedy termin, jak $\mathrm{w}$ procesie zwyczajnym, dni dziesięciu.

Brak apelacji $w$ ciągu dni dziesięciu powoduje tem sam skutek, co dwa jednobrzmiące wyroki za nieważnością i uprawnia strony do zawarcia nowych związków małżeńskich, po opatrzeniu wyroku klauzulą wykonawezą.

Wszelkie adnotacje $w$ księgach parafialnych muszą być dokonane, jak w procesie zwyczajnym.

\section{$\S 10$. Trybunał apelacyjny.}

Trybunał drugiej instancji, w razie apelacji, sprawę rozpatruje $w$ ten sam sposób, jak w instancji niższej, tzn. w trybie skróconym, ponieważ o tym, stosownie do prawa, zadecydował już sędzia pierwszej instancji. Po zbadaniu przeto akt sprawy, po przesłuchaniu stron $\mathrm{i}$ zapoznaniu się $z$ opinią obrońcy węzła, sędzia wydaje wyrok, w którym albo zatwierdza wyrok pierwszej instancji, albo nie zatwierdza. W pierwszym wypadku stronom wolno zawrzeć nowe związki, po otrzymaniu wyroku z klauzulą wykonawcza. W drugim sprawa wraca do trybunału pierwszej instancji, gdzie $\mathrm{mu}$ si być rozpatrzona w trybie $z$ wy $c$ a jnym. Należy przeto utworzyć trybunal kolegialny, trzeba wnieść formalne oskarżenie, zawiązać spór itd. Gdyby chodziło o przeszkodę różnej wiary, a skargę wnosił akatolik, zezwolić musi na to Kongregacja św. Oficjum ${ }^{43}$.

43 Art. 230. Por. Johnson J., j. w.. 638; Dohen y W.; j. w., 175. 
W związku z trybunalem apelacyjnym w procesie skróconym jest wyjaśnienie Komisji Interpretacyjnej z 6.XII.1953 r. Na pytanie mianowicie:

Utrum sub verbis: iudex secundae instantiae, de quibus in cann. 1991 et 1992, veniat tantum episcopus, an etiam officialis.

Resp. Negative ad primam partem, affirmative ad secundam44.

Ani Kodeks Prawa Kanonicznego, ani Instrukcja Kongregacji Sakramentów nie wspominają o tym, jak ma się zachować obrońca węzła, gdy w drugiej instancji zapadnie wyrok zatwierdzający $w$ trybie skróconym wyrok instancji niższej. Czy mianowicie może on apelować jeszcze wyżej, do trzeciej instacji? Nie ulega wątpliwości, że może. Obrońca węzia $z$ urzędu jest obowiązany do obrony małżeństwa. Gdyby więc $\mathrm{w}$ roztropnym sumieniu swoim uważal, że proces $\mathrm{w}$ trybunale drugiej instancji nie stwierdził faktu istnienia przeszkody, albo nie udowodnil faktu braku dyspensy, zawsze może apelować wyżej; w ten sposób spełnia on swój obowiązek, nạ którego wierne wykonywanie złożył przysięgę.

Proces skrócony w prawie Kościoła Wschodniego45.

Can. 498. Cum ex certo et authentico documento, quod nulli contradictioni vel exceptioni obnoxium sit, constiterit impedimentum disparitatis cultus, ordinis, voti castitatis emissi in p:ofessione maiore, ligaminis, consanguinitatis, affinitatis aut cognationis spiritualis simulque pari certudine, ex certo et authentico documento vel etiam alio legitimo modo habita, apparuerit dispensationem super his impedimentis datam non esse, hisce in casibus, praetermissis sollemnitatibus hucusque recensitis, poterit Ifierarcha loci, citatis partibus, matrimonii nullitatem sententia declarare, cum interventu tamen defensoris vinculi.

Can. 499. Adversus hanc sententiam defensor vinculi, si prudenter existimaverit impedimenta de quibus in can. 498 non esse certa aut dispensationem ab iisdem probabiliter interscessisse, provocare debet ad iudicem secundae instantiae, ad quem acta sunt transmittenda quique scripto monendus est agi de casu excepto.

Can. 500. Iudex alterius instantiae, cum solo interventu defensoris vinculi, decernet eodem modo de quo in can. 498, utrum sententia sit confirmanda, an potius procedendum in causa sit ad ordinarium tramitem iuris; quo in casu eam remittit ad tribunal primae instantiae.

44 AAS 36 (1944) 94.

45 AAS $42(1950), 5$.

Prawo Kanoniczne - 5 
Streszczenie.

1. Trybunał w malżeńskim procesie skróconym jest jednoosobowy. Sądzi sam ordynariusz lub z jego upoważnienia oficjał.

2. Przedmiotem procesu skróconego jest małżeństwo zawarte z przeszkodą zrywającą różnej wiary, wyższych święceń, uroczystego ślubu czystości, węzia, pokrewieństwa, powinowactwa i pokrewieństwa duchowego, jeżeli nie było od nich dyspensy.

3. Fakt istnienia jednej $z$ wyliczonych przeszkód $i$ braku dyspensy stwierdza się zasadniczo przy pomocy dokumentów, które nie budzą wątpliwości ani pod względem pewności, ani autentyczności.

4. Po stwierdzeniu właściwości sądowej, prawa stawania w sądzie, istnienia podstaw prawnych, przy udziale obrońcy węzła, $w$ badaniu wstępnym, oficjał referuje sprawę ordynariuszowi, który decyduje wedlug swego sumienia, czy sprawa może być osądzona $w$ postępowaniu skróconym, czy też ma być odesłana na drogę postępowania zwykłego.

5. Jeżeli zapadnie decyzja na rzecz postępowania skróconego, na oznaczony dzień wzywane są strony, obrońca węzła i ewentualnie promotor sprawiedliwości. Strony badane są według pytań obrońcy węzła głównie na okliczność istniejącej przeszlsody, braku dyspensy, względnie uważnienia małżeństwa. Poza tym bađane są także szczegółowo dokumenty przediożone do sprawy, czy są prawdziwe i autentyczne.

6. W procesie skróconym nie ma formalnej skargi, zawiązania sporu publikacji akt, zamknięcia sprawy.

7. Wyrok oglasza ordynariusz względnie oficjał i musi byé umotywowany in iure et in facto.

8. Od wyroku obrońca węzła nie ma obowiązku zakiadać apelacji do wyższej instancji. Gdyby jednak $w$ sumieniu swoim uważał, że istnienie przeszkody nie jest pewne, albo mial wątpliwości, czy nie została udzielona dyspensa, wtedy może założyć apelację $w$ ciągu dni dziesięciu.

9. Instancja wyższa sprawe rozpatruje tak, jak $w$ instancji niższej.

10. Wyrok $w$ sadzie apelacyjnym albo zatwierdza wyrok pierwszej instancji, albo nie zatwierdza. W drugim wypadku sprawa wraca do sądu pierwszej instancji, gdzie musi być rozpatrywana $w$ trybie postępowania zwyczajnego. 